\title{
Description of gastrointestinal parasitism through coprologic survey in Darwin's fox, Lycalopex fulvipes (Martin 1837), and kodkod, Leopardus guigna (Molina 1782), in Chiloé island, Chile
}

\author{
Descripción del parasitismo gastrointestinal mediante análisis coprológico en zorro de \\ Darwin, Lycalopex fulvipes (Martin 1837), y güiña, Leopardus guigna (Molina 1782), en \\ isla de Chiloé, Chile
}

\author{
Gerardo Acosta-Jamett ${ }^{1 *}$, Sol Contreras ${ }^{1}$, Pamela Muñoz ${ }^{2}$, Cristóbal Briceño $^{3,4}$, Catherine \\ ChIRGWIN ${ }^{5}$ \& FELIPE HERNÁNDEZ ${ }^{1}$
}

\author{
${ }^{1}$ Instituto de Medicina Preventiva Veterinaria y Programa de Investigación Aplicada en Fauna Silvestre, Universidad Austral \\ de Chile, Valdivia, Chile. \\ ${ }^{2}$ Instituto de Patología Animal, Universidad Austral de Chile, Valdivia, Chile. \\ ${ }^{3}$ Conserlab, Medicina Preventiva Animal, Facultad de Ciencias Veterinarias y Pecuarias, Universidad de Chile, Santiago, \\ Chile. \\ ${ }^{4}$ Primate Immunogenetics and Molecular Ecology Research Group, Biological Anthropology Department, University of \\ Cambridge, Cambridge, United Kingdom. \\ ${ }^{5}$ Universidad Mayor, Santiago, Chile. \\ *E-mail: gerardo.acosta@uach.cl
}

\begin{abstract}
We aimed to identify faeces belonging to either Darwin's fox (Lycalopex fulvipes) or kodkod (Leopardus guigna) by using molecular genetic techniques, and to describe and compare the gastrointestinal parasites harbored by both carnivores in Chiloé Island. We found that 60\% (25/42) and 88\% (28/32) of faeces of Darwin's fox and kodkod had parasite eggs. This study provided the first record of Aspiculuris sp. and trematodes in Darwin's fox and Aspiculuris sp., Trichuris sp., Capillaria sp., Isospora sp. and trematodes in kodkod, which may correspond to either prey- or host-originated parasites.

\section{RESUMEN}

Nuestro objetivo fue identificar heces pertenecientes a zorro de Darwin (Lycalopex fulvipes) o güiña (Leopardus guigna) utilizando técnicas de genética molecular, y describir y comparar los parásitos gastrointestinales albergados por ambos carnívoros en la isla de Chiloé. Encontramos que 60\% (25/42) y 88\% (28/32) de heces de zorro de Darwin y güiña tuvo huevos de parásito. Este estudio entregó el primer registro de Aspiculuris sp. y tremátodos en zorro de Darwin y Aspiculuris sp., Trichuris sp., Capillaria sp., Isospora sp. y tremátodos en güiña, que podrían corresponder a parásitos de presas u hospederos.
\end{abstract}

The Darwin's fox, Lycalopex fulvipes (Martin 1837), and the kodkod, Leopardus guigna (Molina 1782), live sympatrycally on the Island of Chiloé (Chile), these being the only representatives of their respective families in this area. The Darwin's fox is an endemic species of Chile, found mainly in the Chiloé Island, Los Lagos region $\left(42^{\circ} \mathrm{S}, 74^{\circ} \mathrm{W}\right)$, and also the Nahuelbuta National Park, Araucanía region $\left(37^{\circ} 45^{\prime} \mathrm{S}, 73^{\circ} 00^{\prime} \mathrm{W}\right)$, and surrounding sectors (Jiménez \& McMahon 2004; Moreira-Arce et al. 2015). However, recent findings have placed it outside the Nahuelbuta mountain range in the Araucanía region and Los Ríos regions (D'elía et al. 2013; Farías et al. 2014). Internationally, the Darwin fox is considered by the IUCN as an endangered species with a population tending to decline (Silva-Rodríguez et al. 2016).

The kodkod is the smallest species of neotropical felines (Nowell \& Jackson 1996). It has one of the most restricted distributions, geographically located in a narrow strip between Chile and Argentina, between $33^{\circ}$ to $50^{\circ}$ of latitude $\mathrm{S}$ and $70^{\circ}$ to $75^{\circ}$ of longitude W (Redford \& Eisenberg 1992). In Chile, its distribution expands from the province of Santiago to Chiloé Island and the Guaitecas, while in Argentina, it is confined to a small area on the 
eastern slopes of the Andes in the provinces of Neuquén, Río Negro, and Chubut (Sunquist \& Sunquist 2002). The kodkod is considered a vulnerable species according to the IUCN (Napolitano et al. 2015).

The parasitic fauna of these species is not completely registered and there is only one study on Darwin's fox faeces carried out in the Chiloé Island (Jiménez et al. 2012). For kodkod, few parasitic studies have been performed mainly on the basis of necropsies of animals found dead, and not on coproparasitic exams (Fernández \& Villalba 1984; González-Acuña et al. 2010).

However, distinguishing among morphologically similar faeces of sympatric, similar-sized carnivores can be difficult (Davison et al. 2002), and uncertainty and errors in identification could result in biased data due to the inclusion of samples from non-target species (Farrell et al. 2000; Prugh \& Ritland 2005). For instance, the implementation of molecular genetic analyses for identification of the species from which faeces originated, has become an efficient methodological tool to identify several carnivore species (e.g. Palomares et al. 2002; Wan et al. 2003; Zuercher et al. 2003). In this study, we aimed 1) to identify faeces belonging to either Darwin's fox or kodkod by using molecular genetic techniques, and 2) to describe the gastrointestinal parasites harbored by Darwin's fox and kodkod in Chiloé Island.

During January and February 2011, Tantauco Park $\left(43^{\circ} 5^{\prime} \mathrm{S}, 7^{\circ} 6^{\prime} \mathrm{W}\right)$ was visited on the Chiloé Island, where 94 fresh faeces from the ground were collected (Figure 1). Since faeces were collected during a two-month period over trails within the Park it is likely that the same individual produced some of them. Collected samples were stored in Falcon tubes $(50 \mathrm{ml})$ with $70 \%$ ethanol for their preservation and geographic coordinates recorded using a GPS (Garmin Etrex model). Initially, faeces were visually identified as belonging to Darwin's fox if they contained seeds, while faeces without seeds where assigned to kodkod. To account
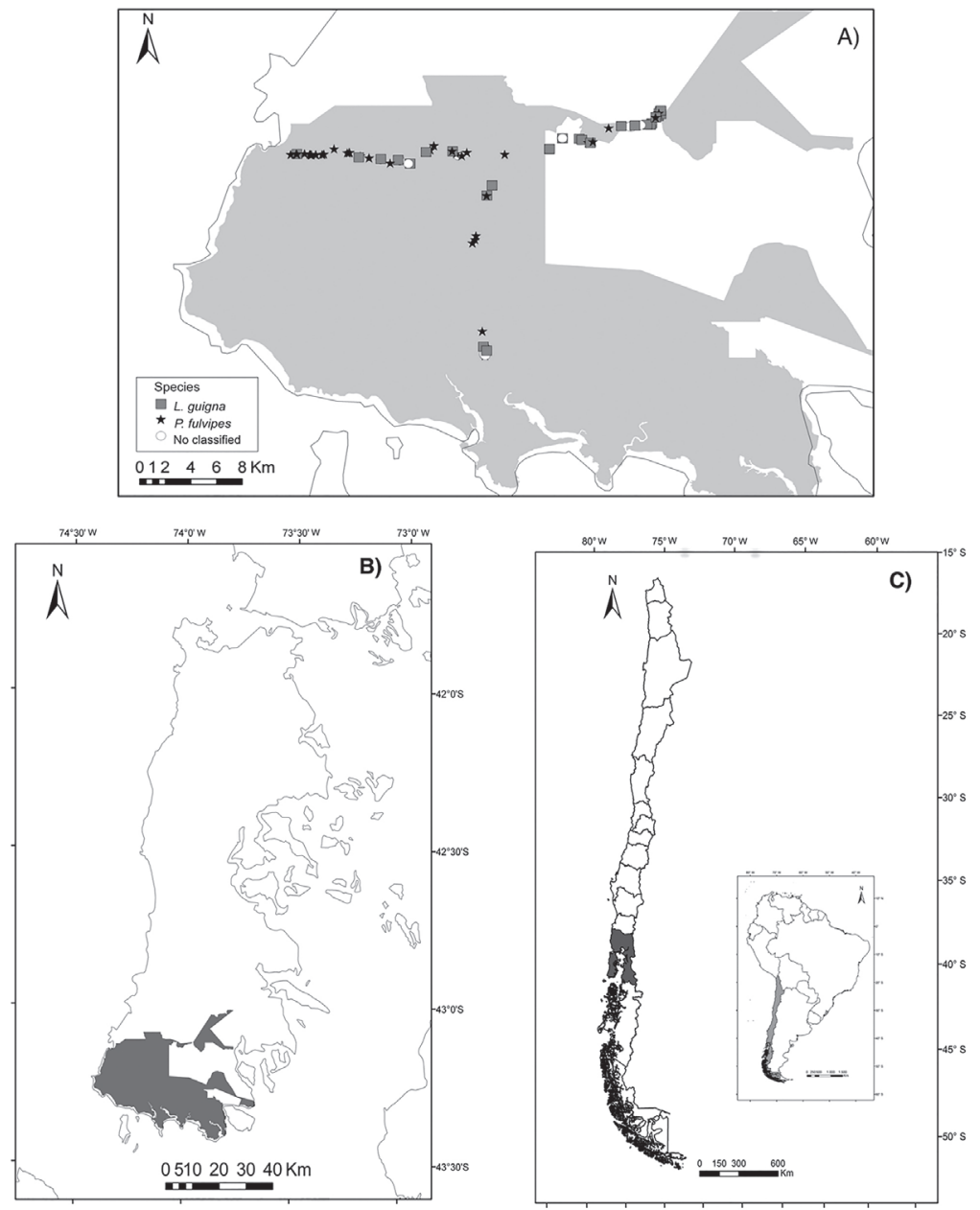

FigurE 1. A) Location of collected faeces belonging to kodkod and Darwin's fox in the study area in the Chiloé Island, Chile. Zone colored in gray denotes the Tantauco Park limits. B) and C) Location of the Tantauco Park in Chile. / A) Localización de fecas recolectadas de güiña y zorro de Darwin en el área de estudio en Isla de Chiloé, Chile. Zona coloreada en gris denota los límites del Parque Tantauco. B) y C) Localización del Parque Tantauco en Chile. 
for misleading species identification, we conducted genetic analyses on all collected faeces. Genomic DNA was extracted from faeces using a QIAamp Stool DNA mini kit (Qiagen Ltd., West Sussex, RH10 9NQ, UK) at the Primate Immunogenetics and Molecular Ecology Research Group (PRIME) at the University of Cambridge, Great Britain. The cytochorme $b$ region of the mitochondrial DNA was amplified using a subset of the described and proprietary designed primers, standard reagents and PCR (Briceño et al., in prep). PCR products were sequenced by standard capillary electrophoresis, and results analyzed using MEGA 5.0 (Tamura et al. 2011) and available data for comparison and species identification, extracted from GenBank.

Parasitic identification was conducted using the qualitative sedimentation-flotation technique with zinc sulfate (Teuscher 1965, Hendrix \& Robinson 2012), where eggs and oocysts were measured, photographed and identified by their morphological characteristics, in order to reach the deepest possible taxonomic level (Mehlhorn et al. 1983; Soulsby 1987; Georgi \& Georgi 1994). The prevalence of the positive samples and of each egg genus found in Darwin's fox and kodkod were calculated. We determined the specific richness (S) (total of parasitic species found in the samples of each species) and the average richness (average of the parasitic richness of each sample for each species) with the corresponding standard deviation.

Out of the 94 faeces collected, only 74 could be genetically identified, with 42 corresponding to Darwin's fox and 32 to kodkod. Contrasting the presence of seeds and genetic classification of faeces, we found that 15 faeces we initially classified as kodkod corresponded to Darwin's fox as result of genetic analyses; while four faeces initially classified as Darwin's fox corresponded to kodkod after genetic analyses, totalling $26 \%$ of identification error.

In general, specific richness resulted in eight different species of parasites detected in each carnivore species, determining an average richness (+/- SD) of $0.95+/-1.11$ and $2.16+/-1.55$ species of parasites in fox and kodkod, respectively (Figure 2). In decreasing order, the parasites with highest prevalence found in Darwin's fox correspond to Isospora sp. (31\%), Toxocara canis (24\%) and Capillarinae gen sp. (12\%) and trematode eggs (12\%). In kodkod, parasite prevalence in decreasing order correspond to trematodes eggs (66\%), Toxocara cati (56\%) and Isospora sp. (28\%). When comparing prevalences between Darwin's fox and kodkod, significant differences were found in the global analysis, detecting that $60 \%$ of the fox samples were positive to some type of parasite, unlike the kodkod, where $88 \%$ of the faeces resulted positive (Table 1). When performing the analysis per species, it was found that this difference would be explained by Spirometra sp., Toxocara sp. and trematode eggs, which were more prevalent in kodkod than Darwin's fox (Table 1).

In comparison to the descriptions of Jiménez et al. (2012), in the present study, the parasitic species found in the Darwin's fox only differ in trematode eggs and the nematode Aspiculuris sp., being the first record of these parasites in this carnivore. Jiménez et al. (2012) only determined the presence of eggs of the nematodes Capillarinae gen sp., $T$. canis, Toxascaris leonina, Filaroides osleri, ancylostomatid

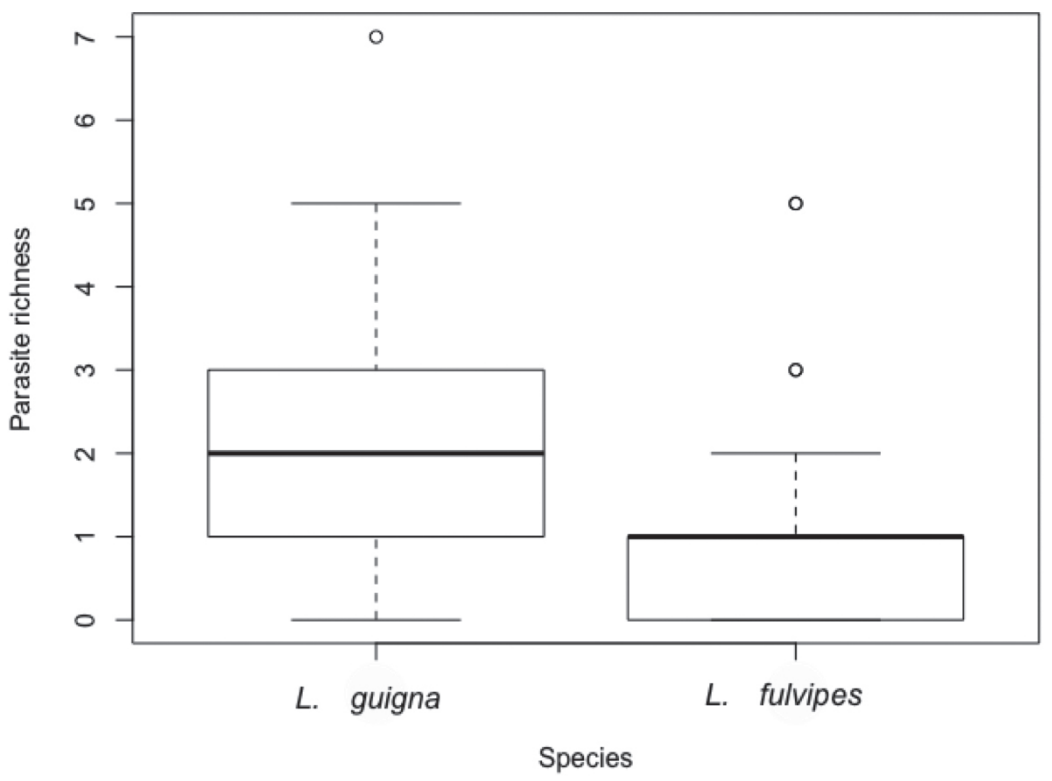

FiguRE 2. Gatrointestinal parasite richness of kodkod and Darwin's fox. The darker line represents the median, the gray box includes 50\% of data, and the white circles depict the outliers. / Riqueza de parásitos gastrointetinales de güiña y zorro de Darwin. La línea más oscura corresponde a la mediana de los valores obtenidos, los cuadros grises agrupan el 50\% de los datos, y los círculos blancos representan los valores atípicos. 
nematodes, Trichuris sp., the cestodes Spirometra sp. and Taenia sp., and the coccidia (Isospora sp.) in Darwin's fox. Similarly, if we analyze the total prevalence of parasite eggs and oocysts obtained by Jiménez et al. (2012) (21.2\%), this is evidently lower than the prevalence found in this study (60\%). Differences in the identified parasite species and prevalence could be due to use of one additional technique by Jiménez et al. (2012) to identify parasites (i.e. sugar flotation), and the fact these authors collected and analysed faeces from distinct locations across the Chiloé Island. In addition, the method used by Jiménez et al. (2012) for faeces collection was solely based on their visual identification, based on size, shape and color, which according to our study can lead to a biased identification.

TABLE 1. Prevalence of different parasite eggs found in Darwin's fox and kodkod faeces in Chiloé Island. / Prevalencia de diferentes huevos de parásitos encontrados en heces de zorro de Darwin y güiña en la Isla de Chiloé.

\begin{tabular}{lcc}
\hline & $\begin{array}{c}\text { Darwin's fox } \\
(n=42)\end{array}$ & $\begin{array}{c}\text { Kodkod } \\
(n=32)\end{array}$ \\
\hline$N$ positive samples & $25(60 \%)$ & $28(88 \%)$ \\
Nematodes & $10(24 \%)$ & $18(56 \%)$ \\
Toxocara sp. & $1(2 \%)$ & $1(3 \%)$ \\
Toxascaris leonina & $2(5 \%)$ & $3(9 \%)$ \\
Aspiculuris sp. & 0 & $1(3 \%)$ \\
Trichuris sp. & $5(12 \%)$ & $4(13 \%)$ \\
Capillarinae gen sp. & $1(2 \%)$ & $8(25 \%)$ \\
Cestodes & $4(10 \%)$ & 0 \\
Spirometra sp. & & $21(66 \%)$ \\
Taeniidae-type & $5(12 \%)$ & $9(28 \%)$ \\
Trematodes & & \\
Sin clasificación & $13(31 \%)$ & \\
Protozoa & Isospora sp. &
\end{tabular}

( ): \% prevalence

In the case of kodkod, description of found parasites differ from the reports of González-Acuña et al. (2010), where only three nematodes were found: T. leonina in the necropsy

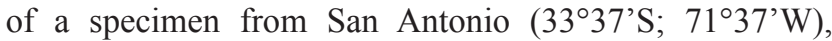
T. cati in a corpse from Pemuco $\left(36^{\circ} 59^{\prime} \mathrm{S} ; 7^{\circ} 1^{\circ} 58^{\prime} \mathrm{W}\right)$ and Mastophorus muris in fecal samples from the Laguna San Rafael National Park. Likewise, the new results disagree with those described by Fernández \& Villalba (1984) who obtained nematodes (Uncinaria stenocephala and T. cati) through the corpse of an individual from Chaimavida $\left(36^{\circ} 50^{\prime} \mathrm{S} ; 7^{\circ} 03^{\prime} \mathrm{W}\right)$ and cestodes (Taenia taeniaeformis, Spirometra mansonoides and Taenia sp.). Therefore, in this study the detection of eggs of the nematodes Aspiculuris sp., Trichuris sp., Capillarinae gen sp., the coccidia Isospora sp. and trematodes, represents the first record of these parasites in kodkod. This amount of new identified species could be due to the fact that the number of individuals possibly sampled through the collection of faeces is much greater than previous studies, where parasitic description was based on necropsy findings from kodkod individuals.
Regarding the source of the identified eggs, they may correspond to either prey- or host-originated parasites. For instance, Aspiculuris sp., Trichuris sp., Capillarinae gen sp. and trematodes are frecuently reported parasitising rodents (eg. Robles et al. 2006; Behnke et al. 2015; Archer et al. 2017; Panti-May et al. 2017); thus, its detection on both kodkod and Darwin's fox faeces could be also likely due to passive transit through the gastrointestinal tract of both carnivores. Although, wild carnivores are also final host of some Trichuris and Capillarinae gen sp. species (eg. Guardone et al. 2013). It is also noteworthy that the majority of endoparasites identified in both Darwin's fox and kodkod have been found in domestic dogs (Alcaino \& Gorman 1999; López et al. 2006; Landaeta-Aqueveque et al. 2014), then we cannot rule out potential parasite transmission between sympatric domestic and wild carnivores in the region.

Differences in the prevalence of positive faeces, and parasite richness between Darwin's fox and kodkod (involving Spirometra sp., Toxocara sp. and trematode eggs) might be related to differential dietary items consumed by 
both carnivores. For instance, kodkod consume vertebrate preys as primary items, such as rodents and birds (Dunstone et al. 2002; Moreira-Arce et al. 2015; Figueroa et al. 2018), which may act as intermediate host in the life cycle of several parasites (Cordero del Campillo et al. 2001); while Darwin's fox diet besides vertebretes is also composed by other several non-vertebrate species which do not harbor gastrointestinal parasites, such as insects, crustaceans and seeds (Jiménez 2007). However, further studies should be carried out to assess which prey species are explaining the differences in parasitism between these species. Further studies about the phylogenetic relationships of the identified parasite species may elucidate the similarities and differences between the gastrointestinal parasite communities harbored by both Darwin's fox and kodkod.

\section{ACKNOWLEDGEMENTS}

This project was financially supported by Parque Tantauco, project Fondecyt No 11100303, The Rufford Small Grant Foundation, Feline Conservation Federation, Becas ChileFONDECYT, Emmanuel College Cambridge and DID$\mathrm{UACH}$.

\section{REFERENCES}

Alcaíno, H, Gorman, T. 1999. Parásitos de los animales domésticos en Chile. Parasitología al día 23:33-41.

Archer, E.K., Bennett, N.C., Junker, K., Faulkes, C.G., LutermanN, H. 2017. The distribution of gastrointestinal parasites in two populations of common mole-rats (Cryptomys hottentotus hottentotus). Journal of Parasitology 103:786-790.

Panti-May, J.A., Caraveo-Centeno, L., Hernandez-Betancourt, S.F., Robles, M.D., Machain-Williams, C. 2017. Survey of intestinal helminths collected from pet rodents in México. Parasitology Research 116(11):3239-3242.

Behnke, J.M., Stewart, A., Bajer, A., Grzybek, M., Harris, P.D., Lowe, A., Ribas, A., Smales, L., Vandegrift, K.J. 2015. Bank voles (Myodes glareolus) and house mice (Mus musculus musculus; M. m. domesticus) in Europe are each parasitized by their own distinct species of Aspiculuris (Nematoda, Oxyurida). Parasitology 142:1493-1505.

Bowman, D. 2008. Diagnostic in parasitology. In: Bowman, D. (Ed). Georgis' Parasitology for Veterinarians: 295-371. Elsevier Inc, USA.

Cordero del Campillo, M., Rojo, F.A., Martínez, A.R., Sánchez, S., Hernández, S., Navarrete, J., Díaz, P., Quiroz, H., Carvalho, M. 2001. Parasitosis del aparato digestivo del perro y el gato. In: Cordero del Campillo, M., Rojo, F.A., Martínez, A.R., Sánchez, S., Hernández, S., Navarrete, J., Díaz, P., Quiroz, H., Carvalho, M. (Eds). Parasitología Veterinaria: 615-651. McGraw-Hill Interamericana, Madrid, España.

Davison, A., Birks, J.D.S., Brookes, R.C., Braithwaite,
T.C., Messenger, J.E. 2002. On the origin of faeces: morphological versus molecular methods for surveying rare carnivores from their scats. Journal of Zoology 257:141-143.

D'elía, G., Ortloff, A., Sánchez, P., Guiñez, B., Varas, V. 2013. A new geographic record of the endangered Darwin's fox Lycalopex fulvipes (Carnivora: Canidae): filling the distributional gap. Revista Chilena de Historia Natural 86:485-488.

Dunstone, N., Freer, R., Acosta-Jamett, G., Durbin, L., Wyllie, I., Mazzolli, M., Scott, D. 2002. Uso del hábitat, actividad y dieta de la güiña (Oncifelis guigna) en el Parque Nacional Laguna San Rafael, XI Región, Chile. Boletín del Museo Nacional de Historia Natural (Chile) 51:147-158.

Farías, A.A., Sepúlveda, M.A., Silva-rodríguez, E.A., Eguren, A., González, D., Jordán, N.I., Ovando, E., Stowhas, P., Svensson, G.L. 2014. A new population of Darwin's fox (Lycalopex fulvipes) in the Valdivian Coastal Range. Revista Chilena de Historia Natural 87:3.

Farrel, L.E., Roman, J., Sunquist, M.E. 2000. Dietary separation of sympatric carnivores identified by molecular analysis of scats. Molecular Ecology 9:1583-1590.

Fernández, J., Villalba, C. 1984. Helmintos parásitos de Felis guigna Molina, 1782 (Carnivora, Felidae). Boletín de la Sociedad de Biología de Concepción 55:161-164.

Figueroa, R.A., Corales, E.S., Rau, J.R. 2018. Prey of the güiña (Leopardus guigna) in an Andean mixed southern beech forest, southern Chile. Studies on Neotropical Fauna and Environment 53:211-218. doi.org/10.1080/01650521.201 8.1477032 .

Georgi, J., Georgi, M. 1994. Parasitología en Clínica Canina. Editorial Interamericana Mc.GrawHill, Ciudad de México.

González-Acuña, D., Moreno, L., Ardiles, K., Flores, M., Duclos, M., Kinsella, M. 2010. Endoparasites of the kodkod, Oncifelis guigna (Carnivora, Felidae) in Chile. Revista Chilena de Historia Natural 83:619-622.

Guardone, L., Deplazes, P., Macchioni, F., Magi, M., Mathis, A., 2013. Ribosomal and mitochondrial DNA analysois of Thricuridae nematodes of carnivores and small mammals. Veterinary Parasitology 197:364-369.

Hendrix, C., Robinson, E. 2012. Diagnostic Parasitology for Veterinary Technicians. $4^{\circ}$ Edición, Elservier, USA. 316319 pp.

JiMÉNEZ, J.E. 2007. Ecology of a coastal population of the critically endangered Darwin's fox (Pseudalopex fulvipes) on Chiloe Island, southern Chile. Journal of Zoology 271:63-77.

Jiménez, J.E., Briceño, C., Alcaíno, H., VÁsquez, P., Funk, S., GonzÁlez-Acuña, D. 2012. Coprologic survey of endoparasites from Darwin's fox (Pseudalopex fulvipes) in Chiloe, Chile. Archivos de Medicina Veterinaria 44:93-97.

Jiménez, J., Mcmahon, E. 2004. Darwin's fox, Pseudalopex fulvipes. In: Sillero-Zubiri, C., Hoffmann, M., Macdonald, D.W. (Eds). Canids: foxes, wolves, jackals and dogs. Status survey and conservation action plan: 50-55. IUCN/SSC Canid Specialist Group. Gland, Switzerland and Cambridge, UK.

Landaeta-Aqueveque, C., Henríquez, A., Cattan, P.E. 2014. Introduced species: domestic mammals are more significant transmitters of parasites to native mammals than are feral mammals. International Journal for Parasitology 44:243-249. 
López, D., Abarca, K., Paredes, P., Inzunza, E. 2006. Parásitos intestinales en caninos y felinos con cuadros digestivos en Santiago, Chile. Consideraciones en Salud Pública. Revista médica de Chile 134:193-200.

Mehlhorn, H., Düwel, D., Raether, W. 1983. Manual de parasitología veterinaria. Editorial Grass - Iatros, Bogotá.

Moreira-Arce, D., Vergara, P.M., Boutin, S. 2015. Diurnal human activity and introduced species affect occurrence of carnivores in a human-dominated landscape. PLoS ONE 10(9):e0137854.

Moreira-Arce, D., Vergara, P.M., Boutin, S., Simonetti, J.A., Briceño, C., Acosta-Jamett, G. 2015. Native forest replacement by exotic plantations triggers changes in prey selection of Mesocarnivores. Biological Conservation 192:258-267.

Napolitano, C., Gálvez, N., Bennett, M., Acosta-Jamett, G., SAnderson, J. 2015. Leopardus guigna. The IUCN Red List of Threatened Species 2015: e.T15311A50657245. URL: http://dx.doi.org/10.2305/IUCN.UK.2015-2.RLTS. T15311A50657245.en. Accessed: January 9, 2018.

Nowell, K., JACKSON, P. 1996. Wild cats: status survey and conservation action plan. IUCN/SSC Cat Specialist Group, Gland. 383 pp.

Palomares, F., Godoy, J.A., Piriz, A., O’Brien, S.J., Johnson, W.E. 2002. Faecal genetic analysis to determine the presence and distribution of elusive carnivores: design and feasibility for the Iberian lynx. Molecular Ecology 11:2171-2182.

Prugh, L.R., Ritland, C.E. 2005. Molecular testing of observer identification of carnivore feces in the field. Wildlife Society Bulletin 33:189-194.

R Core TeAm. 2013. R: A language and environment for statistical computing. R Foundation for Statistical Computing, Vienna, Austria. URL: http:/www.R-project.org/. Accessed: January 9, 2018

RedFord, K.H., EisenBERG, J.F. 1992. Mammals of the Neotropics: the southern cone: 2, The southern cone: Chile, Argentina,
Uruguay, Paraguay. University of Chicago Press. Chicago, IL. $430 \mathrm{pp}$.

Robles, M.D., Navone, G.T., Notarnicola, J. 2006. A new species of Trichuris (Nematoda: Trichuridae) from Phyllotini rodents in Argentina. Journal of Parasitology 92:100-104.

Silva-Rodríguez, E., Farías, A., Moreira-Arce, D., Cabello, J., Hidalgo-Hermoso, E., Lucherini, M., Jiménez, J. 2016. Lycalopex fulvipes (errata version published in 2016). The IUCN Red List of Threatened Species 2016:e. T41586A107263066. URL: http://dx.doi.org/10.2305/ IUCN.UK.2016-1.RLTS.T41586A85370871.en. Accessed: January 9, 2018.

Soulsby, E.J.L. 1987. Parasitología y enfermedades parasitarias en los animales domésticos. $7^{\mathrm{a}}$ Edición. Nueva Editorial Interamericana, Ciudad de México.

Sunquist, M., Sunquist, F. 2002. Kodkod, Oncifelis guigna (Molina, 1782). In: Sunquist, M., Sunquist, F. (Eds). Wild Cats of the World: 211-214. University of Chicago Press. Chicago, IL.

Tamura, K., Peterson, D., Peterson, N., Stecher, G., Nei, M., Kumar, S. 2011. MEGA5: Molecular evolutionary genetics analysis using maximum likelihood, evolutionary distance, and maximum parsimony methods. Molecular Biology and Evolution 28:2731-2739.

Teuscher, E. 1965. A new single method of examining faeces for the diagnosis of helminth diseases of ruminants. Zentralbl Veterinarmed B 12:241-248.

Wan, Q.H., Fang, S.G., Chen, G.F., Wang, Z.M., Ding, P., Zhu, M.Y., Chen, K.S., Yu, J.H., Zhao, Y.P. 2003. Use of oligonucleotide fingerprinting and faecal DNA in identifying the distribution of the Chinese tiger (Panthera tigris amoyensis Hilzheimer). Biodiversity and Conservation 12:1641-1648.

Zuercher, G.L., Gipson, P.S., Stewart, G.C. 2003. Identification of carnivore feces by local people and molecular analyses. Wildlife Society Bulletin 31:961-970.

Recibido: 16.03 .2018

Aceptado: 27.08.2018 